\title{
WHAT OF THE NIGHT? CONCEPTIONS OF NIGHT IN PROVERBS, ECCLESIASTES AND SONG OF SONGS
}

\author{
...Watchman, what of the night? ...The morning cometh, and also the night: \\ If ye will inquire, inquire ye... (Isa. 21:11-12)
}

Funlola Olojede

Stellenbosch University

\begin{abstract}
This article investigates the conceptions of night in the books of Proverbs, Ecclesiastes and Song of Songs in the light of the theology of night in the book of Job and the Psalter. It is noted that though some levels of correspondence are observable in the understandings of night in Proverbs-Ecclesiastes-Song of Songs and in Job-Psalter, the points of divergence are stronger. Whereas a strong feminist case can be made regarding the depictions of night especially in Proverbs and Song of Songs, evidence from Job-Psalter differs. In contrast, the unmistakable focus on God in the Job-Psalter conceptions of the night is completely absent in ProverbsEcclesiastes-Song of Songs.
\end{abstract}

Key Words: Night; Proverbs; Ecclesiastes; Song of Songs; Darkness

\section{Introduction}

Although today wisdom literature is largely narrowed down to Job, Proverbs and Ecclesiastes, traditionally, Proverbs, Ecclesiastes and Song of Songs were classified together with Job and Psalms as wisdom books. ${ }^{1}$ In a number of commentaries, the books of Proverbs, Ecclesiastes and Song of Songs are interpreted in one single volume, ${ }^{2}$ which shows that these books are not exactly strange bedfellows and grouping them together in a single analysis is not considered out of place. Moreover, in the Christian Canon, Proverbs, Ecclesiastes and Song of Songs follow Job and the Psalms even though in the Jewish canon, the Ecclesiastes and Song of Songs are grouped together with Ruth and Esther and Lamentations as the Megilloth ${ }^{3}$ (Five Scrolls). This study examines the conceptions of night in the books of Proverbs, Ecclesiastes and Song of Songs as a sequel to an earlier analysis of night in the book of Job and the Psalter.

One could pass over the definition of night and the relationship between night and darkness which have already been addressed in a previous treatise ${ }^{4}$. It has been established that because both Job and the Psalter make use of direct speech, "Most of the hints about night are expressed in direct speech and they constitute mainly the reflections of the speakers on night as well as their experiences in the night, or the night time activities"5. A textual analysis of the conceptions of night in the two books therefore shows both correspondence and dissonance. Night is often used in contrast with day but the distinction between night and day is also sometimes blurred. The night time activities are expressed in both positive and negative imagery and are carried out by both human and non-human actors including God, animals, the elements, etcetera. For instance, whereas night is a time of rest and of positive interaction between God and the righteous, night time could also be a 
time of dread, pain, assault, affliction and tears. But God remains supremely in control of the night as well as its activities and its other actors.

Unlike the corpus of Job-Psalter that contains numerous occurrences of the term night, the string of Proverbs through Song of Songs presents only terse references to night. Because of the scant mention of the word, the analysis will consider other concepts that are associated with night such as dark(ness), sleep, bed, candle/lamp in order to get a fuller picture of night in the three books. In what follows therefore, I shall offer a brief background to each book before considering the concept of night in it. The findings from the three books will then be appraised in the light of Job and the Psalter.

\section{Night time in the Book of Proverbs}

Much has been written about the Sitz-im-Leben of the book of Proverbs. Divergent views of scholars on the primary institution for the dissemination of wisdom instructions in the book claim that this could have been the royal court, the household or the scribal schools. And whereas the spatial setting for the wisdom speeches in Proverbs 1-9 include the market places, the city square, the pathway, the city gate and the city walls, ${ }^{6}$ Whybray argues persuasively that the unit of Proverbs 1-9 has its social and material background in an urban, city setting based on various allusions to the busy life of an Israelite city and that the many descriptions of the houses, streets and squares, and the invitations to dinner parties all point to a city and not to a village life. He shows that the text expresses the interests of wealthy, self-satisfied, upper-class urban-dwellers. ${ }^{7}$

However, little has been said about the temporal setting of Proverbs. The temporal setting of an event or experience is integral to the event, as events and occasions are timebound or distinguished by time. ${ }^{8}$ Hendrik Bosman (in honour of whom this article is presented) has also rightly noted that "the acknowledgement that the understanding of time inevitably impacts on the comprehension of history..." Although the focus of this article is on night time, the investigation could help us to understand in part the overall temporal setting of the book of Proverbs.

In Proverbs, overt mention of the word night is limited to only three references, namely Proverbs $7: 9 ; 31: 15,18$. It is remarkable that none of these is found in the sentence literature. Whereas the first occurrence is found in the unit of Proverbs 1-9, the last two references to night occur in the classical poem about the eshet hayil in the unit of 31:10$31 .{ }^{10}$ Could one then base an argument on such limited data? The initial reaction may be in the negative but a more careful look at the evidence in the light of the conceptions of night in the adjoining books as well as related concepts in the book itself could offer a clearer understanding of the notion of night in Proverbs.

In the sentence literature (Pro. 10-29), there is no direct mention of the word night but throughout the book allusion to night occurs in a few scattered references to sleep $(3: 24$; $4: 16 ; 6: 4,9-10,22)^{11}$ or associated terms, such as bed $\left(7: 16-17,{ }^{12} 26: 14 ; * 22: 7\right)$, candle/lamp $(6: 23 ; 13: 9 ; 20: 20 ; 24: 20)$ and dinner $(15: 17)$. Other temporal terms such as morning $(7: 18 ; 27: 14)$, day and the metaphorical use of the term darkness (cf. $2: 13 ; 4: 19$; 20:20) are thinly spread across the book.

Let us consider the first reference to night which is Proverbs 7:9 and is found in the context of a warning instruction from a parent to a son. In the admonition which flows from the previous chapter, the young man is encouraged to embrace wisdom because it would keep him from falling into the trap of the strange woman (isha zara). Proverbs 7:6-23 then offers a portrait of what transpires between a young man who is being seduced by a strange or adulterous woman from the perspective of the parent who watches the interaction from 
the window of his house $(7: 6)$. The scene unfolds in the street, by the corner of the house of the isha zara $(7: 8,12)$ whose husband has gone on a business trip $(7: 19-20)$ at "twilight, in the evening, in the black and dark" night (7:9). The image of one looking out of the window while young people roam the streets alludes to evening time when people are through with the day's work and are trying to unwind. References to the woman's bed $(7: 16,17)$ also confirm that the Proverbs 7 encounter took place at night, echoing Job's observation that the adulterer operates at night (Job 24:15). Loader points out that "The darkness is presented as a motif with literary function: the seductress speaks in the secrecy of darkness, whereas the words of wisdom are spoken openly..."13

But the encounter does not end as a playful banter in the street, the man is lured to the house of the so-called strange woman where they would take their "fill of love until morning" (7:18). Is it the beauty of the woman or the beauty of the night that seduces this young man? Is it the scent of the woman's perfume or the fragrance of what is probably a spring or midsummer night that charms this undiscerning youth? We may never know. But unknown to the young man, the woman's house is a point of no return. The scene that moves from the street to the chamber of the strange woman would close in the chambers of hell (7:27). The evening of restlessness indeed ushers in the night but that night of pleasure is an ominous night that foreshadows a morning that would break in Sheol.

We have seen that the other two occurrences of 'night' in Proverbs are in the epilogue to the book in $31: 15,18$. The poem which is an ode to the eshet hayil describes her activities, how she conducts her business and how she relates to her husband $(31: 11,28)$, her maidens (31:15), her children (31:28), as well as the poor and the needy (31:20). Even though she has engaged in all kinds of activities during the day, this bionic woman rises up "while it is yet night" to cook for her household (31:15). As a matter of fact, when she sleeps, she is not really asleep because her candle does not go out at night (31:18), which implies that she has attuned herself to take only minimum rest and be ready to get up spontaneously.

In Proverbs 7, the night time actors include the isha zara, the undiscerning young man, and the narrator who admonishes the young man. The whole night scene is captured by the lens of this narrator who is evidently an older man and plays the double role of participant and witness. The woman's husband is absent from the scene, and her children, if there are any, are probably asleep. Thus, we see that night is a time when gullible young men not only seek to play the game of desire but also end up being game. It is also a time when women of the night ply their trade. What is common to both the young men and the young women is their sexual appetite at night. In Proverbs 31:10-31 on the other hand, it seems the eshet hayil is the only one awake as she prepares for another day. Her household is asleep but her candle continues to burn. In the few night scenes in Proverbs therefore, the actors are both male and female. However, two contrasting images of the nocturnal activities of two female characters are noticeable. While the harlot (Strange Woman) operates at night, under the cover of darkness (7:8-23), the eshet hayil also keeps awake at night $(31: 15,18)$. The former is out in the public sphere - in the street corners, "in the black and dark night" (7:9), unabashedly soliciting male customers to take home for the night but the latter is already settled at home toiling by the candlelight (31:18). And whereas the young man is being warned to stay clear of the Strange Woman, the eshet hayil is praised for her works.

Thus, in the book of Proverbs, night is depicted as a time of sexual desire, of hard work and of rest. 


\section{Ecclesiastes - and Nightfall?}

Although the book of Ecclesiastes is classified as wisdom literature, many commentators regard the reflections of the Preacher as a deconstruction of the conventional mainstream wisdom of his time. ${ }^{14}$ It is assumed that at the time of his musings which he renders largely in a narrative form, Qoheleth is an old man approaching the end of life and he seeks to give counsel to young men who love leisure and pleasure. ${ }^{15}$

In Ecclesiastes, only two clear occurrences of night are found and both are part of Qoheleth's sayings. In Ecc. 2:23, night is linked to rest even though in the verse it is actually an acknowledgement that for the labouring man, the night which is supposed to be a time of rest is a time of restlessness of the mind, of anxious thoughts. In Ecc. 8:16, night is paired with the day, as in several psalms. Qoheleth concludes that the activities going on under the sun could prevent one from sleeping, not only at night but in the daytime as well, ${ }^{16}$ hence linking night with sleep or rest. Besides these two mentions of night, Qoheleth's concept of the night can only be teased out from other notions associated with night or its activities or that contrast with night. He talks about sleep (Ecc. 5:12) which though is not restricted to the night most often takes place at night, and of the bedroom $(10: 20) .{ }^{17} \mathrm{He}$ also speaks of darkness or days of darkness $(2: 13,14 ; 5: 17 ; 6: 4 ; 11: 8)$.

However, because night is a unit of time, it is important to mention Qoheleth's reflections on time. Even though he does not refer to night explicitly in his classical ode to time in ch. 3, it can be presupposed that Qohelet's analysis of time ('et) has some collocations that are relevant to night time. ${ }^{18}$ Since there is a strong emphasis on time in the book, it can be argued that whatever his conception of night may be, it is in the context of his notion of time. ${ }^{19}$ If he were to lengthen his poem on time and talk about night and its activities, it would probably have contained "a time to sleep and a time to wake up, a time of night and a time of day, or a time of darkness and a time of light!" In other parts of the book, mention is made of other units of time such as evening (11:6), morning $(10: 16 ; 11: 6)$ which implies that there was a night, and a day, which is used mostly in a metaphorical sense (cf. 2:16; 7:1, 14; 8:8; 12:3, among others).

In the Old Testament, day and night often form a word pair and have corresponding associations with light and darkness. ${ }^{20}$ Light and darkness in Ecclesiastes are regarded as polar opposites. ${ }^{21}$ But what is fascinating here is Qoheleth's extensive use of various images of light in his reflections. His image of light is positive as he says, "Truly the light is sweet and a pleasant thing for the eyes to behold the sun" (11:7; cf. 10:17). He talks of the sun $(1: 5 ; 7: 11 ; 11: 7)$, the moon and the stars $(12: 2)$ and by contrast of the clouds and the rain $(11: 3 ; 12: 2)$. However, his use of the expression 'tahat haššameš' (under the sun), twenty-five times, ${ }^{22}$ to refer to the domain of human beings, is truly remarkable. Elsewhere, he employs the synonymous expression 'under heavens' $(1: 13 ; 2: 3 ; 3: 1)$ or 'earth' $(1: 4$; $3: 21 ; 5: 2,9 ; 7: 20 ; 8: 14,16 ; 10: 7 ; 11: 2,3 ; 12: 7)$ which he could have continued to use but he chooses the alternative term, 'under the sun'. What then could be the reason for this emphasis?

First, it appears that the idea of seeing the sun and light is important to Qoheleth $(7: 11$; 11:7), hence, his persistent effort to draw the gaze of his audience to the sun/light through the expression 'under the sun'. More importantly, it seems to me that the prevalent use of the phrase 'under the sun' as opposed to 'under heaven' is aimed at underscoring the image of light that pervades the book. In fact, Qoheleth uses the expression as a literary device to highlight his strong preference of light to darkness. No doubt, he privileges light over darkness. For instance, in 2:13, he states that light excels or is preferable to darkness which could imply that he privileges the day over the night. But he does not offer any reasons for 
his choice. Noteworthy however is that the privileging of light over darkness recalls creation theology and Genesis 1, where light is called out of darkness and reigns over darkness.

It appears also that Qoheleth had begun to experience disillusionment as he neared the end of his life and the hour of darkness approached (2:15-16). Under the sun, he had loved life and light but now it dawned on him that the sun would soon set and he would be compelled to embrace the night (1:5). All his life, he had enjoyed the warmth and the light of the sun, but soon the curtains would close and he is reminded (and he reminds the youth also) of the days of darkness which would be many (11:8; 12:1-3). So he reverts to copious references to death and mourning $(7: 2-4 ; 12: 5-7)$. As one who is not hesitant to capture some of life's contradictions, Qoheleth here suggests that going to the house of mourning is better than going to the house of feasting and he says the day of death is better than the day of birth. Fox asserts that:

The light that is extinguished in 12:2 is the light that is called sweet in 11:7, namely the light of life. Likewise the darkening of the light is the onset of the eternal darkness mentioned in 11:8. In one sense that is the extinction of an individual life; in another the extinction of a universe. For the person who dies, the light blinks out, the sun goes down (only the living 'see the sun'), activities cease, and the world grows silent. ${ }^{23}$

Does this imply that with death, the day of darkness or the time of night prevails in the end since he says the sun, the moon and the stars will grow dark (12:1-2ff)? Typically, this Preacher does not resolve the tension but leaves the matter open (even though his reflections in chapter 3 could denote a finality of death). It is clear that overt reference to night in Ecclesiastes is rather scant and one could be tempted to conclude that Qoheleth has no deep theological conception of night like Job or the Psalter. However, a closer examination of concepts associated with or that contrast with night shows us that night is not absent but is very much present in the mind of the Preacher. As if to distract his mind from the impending nightfall and the power that it holds, he then takes recourse in the use of various images of light and of the day.

\section{A Song in the Night? Song of Songs and the Time of Love}

The Song of Songs is the Bible's only love poem and it "testifies to a worldview that included a vision of romance in which importance was attached to mutual desire". ${ }^{24}$ Specifically, the SoS is an expression of erotic love and sexual desire. ${ }^{25}$ It expresses in a dialogic form mostly the inner longings of the Shulamite ${ }^{26}$ who engages in a mental search for her lover who is either real or imagined ${ }^{27}$ as well as the longings of her lover. The Shulamite for instance imagines herself with her lover in different locations and scenarios. Different spatial settings are therefore presented in the book. We see, among others, the thoughts of the Shulamite and of her lover veer from the king's bedroom $(1: 4)$ to the banqueting hall $(1: 12 ; 2: 4)$, from her own vineyard $(1: 6 ; 7: 12 ; 8: 12)$ and on her bed $(3: 1)$ to the streets $(3: 2)$ and the city walls $(3: 3 ; 5: 7)$ and the house of her mother $(3: 4 ; 8: 5)$, from the desert $(3: 6 ; 8: 5)$, under the apple tree in the garden $(4: 13,16 ; 5: 1 ; 6: 2-3,11 ; 8: 5,13)$, on the mountains and the hills $(2: 8,14 ; 4: 1,6,8 ; 8: 14)$ to the countryside $(7: 11-12) .{ }^{28}$ Meyers confirms that the Song contains images from settings of nature. ${ }^{29}$

The composition of the Song however relies entirely on speeches, ${ }^{30}$ particularly speeches of two lovers but in these speeches and in the book, clear references to night are not many. This is not surprising given the length of the text. The temporal setting of the SoS is primarily the night, as ch. 3 shows, but images of the dawn (or day), noon and the morning contrast with the night $(1: 7 ; 2: 17 ; 4: 6 ; 6: 10 ; 7: 12)$ while (like in Ecc. 12:2) 
references to the elements - the moon, the stars and the sun strengthen and contrast simultaneously with the night imagery $(1: 6 ; 6: 10)$.

In the Song, the first occurrence of the word night is in SoS 1:13 where the Shulamite compares her beloved to a fragrant pouch of myrrh that spends the night between her breasts. In 3:1, the Shulamite says that she lies all night long on her bed longing for her lover. This is no daydreaming, but a deep yearning at night for the one she loves. The mention of the word 'bed' or 'sleep' immediately conjures the idea of night (cf. 1:16;3:7; $5: 2 ; * 5: 13$ ). Hagerdorn claims that, “...next to the bed as an obvious place for sleeping (or sexual activities), it was also the place for private thoughts..."31 For Keel, "Bed" and 'night' are associated primarily with inactivity, rest and sleep. The two words marking the place and time of the lovers' yearning and seeking are emphasised here at the beginning of the poem to say that love's desire, like other passions (Ps. 36:4[5]; Mic. 2:1), cannot find rest at night..."32

Finding no rest, the Shulamite therefore decides to go out to the city, on the street and in the square to look for him. ${ }^{33}$ But she does not find him. Her action in 3:11 has been compared to that of the Strange Woman in Proverbs $7: 11,{ }^{34}$ for she also combs the streets at night. Perhaps the Shulamite had hoped to be the only night time actor prowling the street. But she finds that the sentinels are also on the street. She enquires from them whether they have come across her beloved. Fortunately, as soon as she passes them, she finds her lover and takes him into the privacy of her mother's house (3:4). This Shulamite seems to be in charge of affairs!

However, the night scene reoccurs after the lover's long speech in 4:1-5:1, and in 5:2, the Shulamite confesses that even though she is supposed to be asleep, her mind is not at rest. It is dreaming. This recalls Qoheleth's observation in 2:23 that the labouring man who is supposed to sleep well at night actually experiences sleeplessness (cf. Job 7:4; 30:17; Ps. 6:6). Hagerdorn remarks that her sleeplessness is produced by distress, not the distress borne out of illness as in the case of the psalmist (Pss. 77:40-5; 102:8; cf. Esth 6:1; Dan. $6: 19)$ but distress due to the absence of the beloved. ${ }^{35}$ It is uncertain however whether the knock she hears on her door is a product of the dream or her lover actually knocking on the door. She has already washed herself and she is in bed, therefore she cannot respond quickly to the knock she hears. She opens the door but he is gone. She returns to the street to look for him, and the incident with the watchmen replays itself.

Seemingly heedless of the so-called terror by night or of the pestilence that walks in darkness, which the Psalmist poignantly describes (90:5-6), she finds that unlike in the previous encounter, the night watchmen now challenge her $(6: 10)$. Her encounter with the watchmen in the streets who may be likened to today's vigilante groups in some African cities, suggests that either she is truly ignorant of the dangers in the streets at night or she is too desperate for love to care. She speaks of being manhandled by the watchmen. The extent of the assault is however unclear even though it is clear that they hurt her deeply (5:7) and it is also not certain whether it is the same set of watchmen that she encountered earlier. Notable is Exum's comment that:

The beating scene is so problematic that it is usually ignored by commentators, or explained away. Is it 'only a dream'? This raises the question, How much of the text is wishing (as opposed to acting)? ... There is a good deal of dreaming, or fantasising, in the Song. Yet it seems the woman has internalised social constraints... If the beating by the watchmen is a dream or fantasy - and we need to keep in mind that this is a poem, not a police report; that is, constructed by a poet - if this is a dream or fantasy, why the need for punishment? Why does a woman face such a threat? ${ }^{36}$ 
Exum later notes that the incident emphasises "the tension between female desire and patriarchal restraint". ${ }^{37}$

If the neighbourhood of the Shulamite is anything like some of ours today, what those watchmen would do to her flesh can only be left to the imagination. It is disturbing that security forces sometimes manhandle the wrong people while the real criminals go scotfree. But here the terror of the night is overpowered by the ambience of desire and love; 3:7-8 indicates that her confidence apparently is in the expectation that her lover's army of sixty soldiers who draw the sword would defend her against any danger in the streets. At any rate, she seems to find or at least know where to find her lover after a harrowing search (6:2-3).

Following another long speech by her lover (6:4-7:9), in 7:11, the Shulamite boldly invites him to come and spend the night with her in the countryside, in the villages. The images of night also diverge from those in Job-Psalter. Compared to the Psalmist and Job who thirst after God in the night season, the singer desires only the lover in the Song of Songs. Even though her meditation on her bed in the night echoes Psalm 4:4 (cf. 77:6), the focus of the Shulamite's meditation is not God but her lover. Here God is not in the picture. Considering that the primary theme of the SoS is love and desire and the language is the language of love ${ }^{38}$ it is not surprising that the Song shows the night time as a time of romance, of desire, of love. But then the night is also a time of threat and assault as well as a time of rest.

Although night is not the temporal setting for the Song as a whole, in the Song, the main night time actors include the Shulamite, her beloved, the night watchmen and her maidens. Mention is made of her mother and her brothers who are evidently behind the stage. But the Shulamite is not the only character who roams the streets at night. After her first encounter with the sentinels, she encounters her lover on the street and brings him to her mother's house (3:3-4). In a later scene, her lover also seeks her. He knocks on her door and receives no answer; therefore, he melts into the night to wander in the streets (5:4-6). She goes after him but also finds him not. In her search, she addresses the daughters of Jerusalem who appear to be on the street as well $(3: 5 ; 5: 8)$. Whereas the sentinels who accost her apparently control the streets at night $(3: 3 ; 5: 7)$, Solomon's sixty bodyguards also travel at night (3:6-8).

\section{Conclusion}

What then can we make of all the above observations of the conceptions of night in Proverbs, Ecclesiastes and Song of Songs especially in the light of Job and the Psalter? Whereas in Job and the Psalter, the terrors of the night are tempered by divine communication, the beauty of the night and the hope of a new day, in the book of Proverbs, the desire of the young man in the night ends in a tragic descent into the gates of Sheol on the one hand, and on the other hand, the eshet hayil holds out her own in the night season and her works praise her in the gates. Like Job-Psalter, the images of the night in Proverbs are both positive and negative.

In Ecclesiastes, the tension between night and day or between darkness and light are unresolved. Rest and restlessness are experienced in the night but Qoheleth deflects from staring night in the face by focusing on the sun. In the Song, love, romance, dreams and desire mingle with violence, disappointment and despair. Yet the Song ends on a positive hopeful note. But Qoheleth's time to love (3:8) may also be linked to the setting of love and romance in the SoS. It is interesting that the lovers in the Song are youth, which suggests that the time to love is the time of youth but also that the observation that there is a time to 
love comes from an old man. The time to love may be the time of youth but the time of love in the Song is at night.

Dominant in both Proverbs and the SoS is the nocturnal roles played by their female characters. Nevertheless, the roles are not the same. Both the Strange Woman in Proverbs 7 and the Shulamite seek a male companion (cf. also Ruth on the threshing-floor in Ruth 3). Both women have desires and each roams the streets, alone, which is remarkable in what is presumably a patriarchal conservative setting. Both issue a bold invitation to the man, promising to spend the night with him (Prov. 7:17-18; SoS 7:11). But whereas, the former is depicted as an adulteress who cheats on an absent husband, the Shulamite is out seeking her lover and not a random stranger in a 'one-night-stand' encounter.

Although the book of Job and the Psalter have so much to say about night, they do not say it all. The findings on night from Proverbs, Ecclesiastes and the Song of Songs seem to complement what has been overlooked by Job-Psalter. Whereas the conception of night in Job-Psalter centres primarily on God who can be viewed as the main nocturnal actor, such a theocentric focus is missing in the texts that have been analysed above. On the other hand, neither Job nor the Psalmist is concerned about love or romance in the night like the lovers in the SoS, but then the violence in the street in the SoS echoes the kind of violence from which the Psalmist cries out to God for deliverance and which is noted also by Job (e.g. Ps. 55:9-10; Job 24:14). The present texts show that mundane everyday activities also take place at night besides the human-divine communication that is established in Job-Psalter.

Unlike in Job and the Psalter, in Proverbs, Ecclesiastes and the Song, the elements - the sun, the moon and the stars - remain in the background. They are passive witnesses of the powers of the night. On a secondary level, the three books like Job-Psalter also acknowledge directly or indirectly that night is a time of rest or sleep (Pro. 3:24; 4:16; 6:4, 9-10, 22; Ecc. 5:12; 8:16; 10:20; SoS 5:2).

In closing, a short tribute to Hendrik L. Bosman, a Doktorvater, mentor and sage like no other, is in order. I wish to thank you for your exemplary wisdom and labour over the years to ensure that wisdom continues to triumph over folly. Permit me to congratulate you on your approaching retirement and for finishing well. As you enter a new season of life and as you sit at the window of your house looking through your lattice or under your own vine and under your own fig tree, may your fountain of wisdom never cease to flow. I do wish you strength in the years ahead, and light, when in many years to come, night eventually falls and the curtains close.

\section{BIBLIOGRAPHY}

Arbel, Daphna V. “My Vineyard, My Very Own, Is for Myself”. Pages 90-101 in The Song of Songs. A Feminist Companion to the Bible. Second Series. Edited by Athalya Brenner and Carole R. Fontaine. Sheffield: Sheffield Academic Press, 2000.

Bosman, Hendrik. "African and Old Testament Concepts of Time and History". Pages 101-112 in Interpreting the Old Testament in Africa: Papers from the International Symposium on Africa and the Old Testament in Nairobi, October 1999. Edited by Mary Getui, Knut Holter and Victor Zinkuratire. New York: Peter Lang, 2001. Brenner, Athalya. “"My' Song of Songs”. Pages 154-158 in The Song of Songs. A Feminist Companion to the Bible. Second Series. Edited by Athalya Brenner and Carole R. Fontaine .Sheffield: Sheffield Academic Press, 2000. 
Camp, Claudia V. Wisdom and the Feminine in the Book of Proverbs. Sheffield: Almond, 1985.

Dell, Katharine J. The Book of Proverbs in Social and Theological Context. New York: Cambridge University Press, 2006.

Exum, Cheryl J. "Ten Things Every Feminist Should Know about the Song of Songs". Pages 24-35 in The Song of Songs. A Feminist Companion to the Bible. Second Series. Edited by Athalya Brenner and Carole R. Fontaine. Sheffield: Sheffield Academic Press, 2000.

Exum, Cheryl J. Song of Songs: A Commentary. Old Testament Library. Louisville, KY: Westminster John Knox Press, 2005.

Exum, Cheryl. "Song of Songs". Pages 247-254 in Women's Bible Commentary. Twentieth-anniversary Edition. Edited by Carol A. Newsom, Sharon H. Ringe and Jacqueline E. Lapsley. Louisville, KY: Westminster John Knox, 2012.

Fox, Michael V. Qoheleth and His Contradictions. Sheffield: Sheffield Academic Press, 1989.

Fox, M.V "Shulammite." Page 1127 in The Anchor Bible Dictionary. Volume 5 (O-Sh). Edited by David Noel Freedman et al. New York: Doubleday, 1992.

Garrett, Duane A. Proverbs, Ecclesiastes, Song of Songs. Nashville: TN: Broadman Press, 1993.

Hagerdorn, Anselm C. "Jealousy and Desire at Night: Fragmentum Grenfellianum and Song of Songs". Pages 206-227 in Perspectives on the Song of Songs. Perspektiven der Hoheliedauslegung. Edited by Anselm C. Hagerdorn . BZAW 346. Berlin: Walter de Gruyter, 2005.

Johnson, L.D. Proverbs, Ecclesiastes, Song of Solomon. Nashville, TN: Broadman Press, 1982.

Keel, Othmar. The Song of Songs: A Continental Commentary. Translated by Fredrick J. Gaiser. Minneapolis, MN: Fortress Press, 1994.

Loader, J.A. Ecclesiastes: A Practical Commentary. Text and Interpretation. Grand Rapids, MI: William B. Eerdmans, 1986.

Loader, James Alfred. Proverbs 1-9. Historical Commentary on the Old Testament. Leuven: Peeters, 2014.

Longman III, Tremper. Song of Songs. Grand Rapids, MI: WB Eerdmans, 2001.

Meyers, Carol. "Gender Imagery in the Song of Songs". Pages 197-212 A Feminist Companion to the Song of Songs. Edited by Athalya Brenner. Sheffield: Sheffield Academic Press, 1993.

Miller, Douglas B. Symbol and Rhetoric in Ecclesiastes: The Place of Hebel in Qohelet's Work. Atlanta: Society of Biblical Literature Press, 2002.

Olojede Funlola O. "Unsung Heroines of the Hebrew Bible: A Contextual Theological Reading from the Perspective of Woman Wisdom". Unpublished Doctoral

Dissertation. Stellenbosch University, Stellenbosch, 2011.

Olojede, Funlola O. "What of the Night? Theology of Night in the Book of Job and the Psalter". OTE 28/3 (2015):724-737.

Pope, Marvin H. Song of Songs: A New Translation with Introduction and Commentary. The Anchor Bible. New York: Doubleday, 1977.

Rylaarsdam, John Coert. Proverbs, Ecclesiastes, Song of Solomon. London: SCM Press, 1964. 
Schoors, Antoon. Ecclesiastes. Historical Commentary on the Old Testament. Leuven: Peeters, 2013.

Sinnott, Alice M. The Personification of Wisdom. SOTSS. Hants: Ashgate, 2005.

Whybray, R.N. Ecclesiastes. Old Testament Guides. JSOT/Sheffield Academic Press: Sheffield, 1989.

Whybray, Roger N. The Book of Proverbs: A Survey of Modern Study. Leiden: Brill, 1995.

Whybray, Roger N. “City Life in Proverbs 1-9”. Pages 243-250 in Jedes Ding Hat Seine Zeit..., Studien zur Israelitischen und Altorientalischen Weisheit. Edited by R.G. Lehmann, E. Otto and A. Wagner. (BZAW 241). Berlin: Walter de Gruyter, 1996.

Wright, Robert J. and Oden, Thomas C. Proverbs, Ecclesiastes, Song of Solomon.

Downers Grove, IL: InterVarsity Press, 2005.

Yoder, Christine Roy. Proverbs (AOTC). Nashville: Abingdon, 2009.

\section{Endnotes}

1 See R.N. Whybray, Ecclesiastes (Old Testament Guides, Sheffield: JSOT/Sheffield Academic Press, 1989), 11.

2 Cf. views by Garret and Wright which take a cue from older commentaries such as Johnson's and Rylaarsdam's. Duane A Garrett, Proverbs, Ecclesiastes, Song of Songs (Nashville, TN: Broadman Press, 1993); Robert J. Wright and Thomas C. Oden, Proverbs, Ecclesiastes, Song of Solomon (Downers Grove, IL: InterVarsity Press, 2005); L.D. Johnson, Proverbs, Ecclesiastes, Song of Solomon (Nashville, TN.: Broadman Press, 1982); John Coert Rylaarsdam, Proverbs, Ecclesiastes, Song of Solomon (London: SCM Press, 1964).

3 See Cheryl Exum, "Song of Songs," in Women's Bible Commentary, eds. Carol A. Newsom, Sharon H. Ringe and Jacqueline E. Lapsley; Twentieth-anniversary edition (Louisville, KY: Westminster John Knox, 2012), 247.

4 By definition, "...night is the unit of time which refers to the period of darkness between sundown and sunrise. It begins in the evening at twilight and ends at dawn." Cf. Funlola O. Olojede, "What of the Night? Theology of Night in the Book of Job and the Psalter," OTE 28/3 (2015):24.

Olojede, "What of the Night," 732.

Alice M. Sinnott, The Personification of Wisdom (SOTSS, Hants: Ashgate, 2005), 57.

Roger N. Whybray, "City Life in Proverbs 1-9" in Jedes Ding Hat Seine Zeit..., Studien zur Israelitischen und Altorientalischen Weisheit, eds. R.G. Lehmann, E. Otto and A. Wagner (BZAW 241, Berlin: Walter de Gruyter, 1996), 245ff. For a detailed discussion of the views of various scholars on the social context of the book of Proverbs and in particular of chs. 1-9, see Katharine J. Dell, The Book of Proverbs in Social and Theological Context (New York: Cambridge University Press, 2006), 24-32.

8 Olojede, "What of the Night," 724.

9 Hendrik Bosman, "African and Old Testament Concepts of Time and History" in Interpreting the Old Testament in Africa: Papers from the International Symposium on Africa and the Old Testament in Nairobi, October 1999, eds. Mary Getui, Knut Holter and Victor Zinkuratire (New York: Peter Lang, 2001), 101.

10 Notably, both 1-9 and 31:10-31 are said to form an inclusio or framework for the entire Proverbs collection. See Claudia V. Camp, Wisdom and the Feminine in the Book of Proverbs (Sheffield: Almond, 1985),48, 185; Roger N. Whybray, The Book of Proverbs: A Survey of Modern Study (Leiden: Brill, 1995), 70; Christine Roy Yoder, Proverbs (AOTC, Nashville, TN: Abingdon, 2009), 299; Funlola O. Olojede Unsung Heroines of the Hebrew Bible: A Contextual Theological Reading from the Perspective of Woman Wisdom (Unpublished Doctoral Dissertation, Stellenbosch: Stellenbosch University, 2011), 78.

11 In Proverbs $19: 15 ; 20: 13 ; 23: 35 b ; 24: 33 ; 26: 24$, the references to sleep do not necessarily imply that it occurs at night time.

12 Loader describes the 'bed' in 7:16-17 as an "element of the seductive arsenal" and the woman's making of the bed could be seen as an "erotic preparation for a night of lust". James A. Loader, Proverbs 1-9 (Historical Commentary on the Old Testament, Leuven: Peeters, 2014), 309.

13 Loader, Proverbs 1-9, 304. 
Whybray, Ecclesiastes, 58; Douglas B. Miller, Symbol and Rhetoric in Ecclesiastes: The Place of Hebel in Qohelet's Work (Atlanta: Society of Biblical Literature Press, 2002), 174-175.

15 Whybray, Ecclesiastes, 20-22.

16 See J.A. Loader, Ecclesiastes: A Practical Commentary (Text and Interpretation, Grand Rapids, MI: William B. Eerdmans, 1986), 104.

17 "The sleep of the laborer is pleasant - whether he eats little or much - but the wealth of the rich will not allow him to sleep" (5:12); “... and do not curse the rich while in your bedroom" (10:20).

18 Note the distinction between time as a point on the temporal continuum and time in terms of events and configuration of circumstances; cf. Michael V. Fox, Qoheleth and His Contradictions (Sheffield: Sheffield Academic Press, 1989), 194-195. Fox argues that the concept of time in Ecclesiastes 3:1-8 "is not a specific time or date... It is an occasion, a type of configuration of circumstances" (his italics); Fox, Qoheleth, 198. For Schoors, the meaning of time in Ecclesiastes is not necessarily chronological, and that "Whereas the Western mentality would distinguish between time and the events that happen within time, to the Hebrew mentality, time and its contents would be identical, 'time is identical with substance', or the event is inconceivable without its time". Antoon Schoors, Ecclesiastes (Historical Commentary on the Old Testament, Leuven: Peeters, 2013), 231.

Of course, the conception of time by the ancients may differ from ours but the idea of night appears universal. Olojede, "What of the Night," 725.

21 Fox, Qoheleth, 183.

22 Ecc. 1:3, 9, 14; 2:11, 17, 18, 19; 2:20, 22; 3:16; 4:1, 3, 7, 15; 5:13, 18; 6:1, 5, 12; 8:9, 15, 17; 9:3, 6, 9, 11, 13; 10:15; Fox, Qoheleth, 165.

23 Fox, Qoheleth, 293; cf. also p. 300.

24 Exum, "Song of Songs," 248.

25 Cheryl J. Exum, Song of Songs: A Commentary (Old Testament Library, Louisville, KY: Westminster John Knox Press, 2005), 1. On issues of authorship, date, composition, genre, style and the historical cultural context of the Song, read Tremper Longman III, Song of Songs (Grand Rapids, MI: WB Eerdmans, 2001), 1-56; Exum, Song, 1-71.

26 Admittedly, one cannot assume that the female voice is always that of the Shulamite in the SoS. The term is used here for convenience. For more on the Shulamite (also Shulammite), see Marvin H. Pope, Song of Songs: A New Translation with Introduction and Commentary (The Anchor Bible; New York: Doubleday, 1977), 596-600. M.V Fox, "Shulammite," in The Anchor Bible Dictionary (eds. David Noel Freedman et al.; Volume 5 (O-Sh); New York: Doubleday, 1992), 1127.

27 Daphna V. Arbel, "My Vineyard, My Very Own, Is for Myself," in The Song of Songs. A Feminist Companion to the Bible (eds. Athalya Brenner and Carole R. Fontaine; Second Series, Sheffield: Sheffield Academic Press, 2000), 91-92.

28 Note that the traditional interpretation that the life setting of the Song was Solomon's wedding to Pharaoh's daughter has been debunked. Many scholars agree that marriage is not present in SoS except probably in the form of fantasy. Cf. Othmar Keel, The Song of Songs: A Continental Commentary (Translated by Fredrick J. Gaiser; Minneapolis, MN: Fortress Press, 1994), 11; Athalya Brenner, “My' Song of Songs in The Song of Songs. A Feminist Companion to the Bible (eds. Athalya Brenner and Carole R. Fontaine; Second Series, Sheffield: Sheffield Academic Press, 2000), 162. Whether the Shulamite and her beloved are married or not is not stated in the text.

29 Carol Meyers, "Gender Imagery in the Song of Songs," in A Feminist Companion to the Song of Songs, ed. Athalya Brenner (Sheffield: Sheffield Academic Press, 1993), 201.

30 Cheryl J. Exum, "Ten Things Every Feminist Should Know about the Song of Songs," in The Song of Songs. A Feminist Companion to the Bible, eds. Athalya Brenner and Carole R. Fontaine; Second Series (Sheffield: Sheffield Academic Press, 2000), 27.

31 Anselm C. Hagerdorn, "Jealousy and Desire at Night: Fragmentum Grenfellianum and Song of Songs," in Perspectives on the Song of Songs. Perspektiven der Hoheliedauslegung, ed. Anselm C Hagerdorn (BZAW 346, Berlin: Walter de Gruyter, 2005), 209.

32 Keel, The Song, 122. The explicit eroticism that is conjured in the night setting in chapter 5 should not be overlooked (cf. SoS 5:1-5).

33 Hagerdorn who compares the poems in 3:1-5 and 5:2-8 with the Greek Fragmentum Grenfellianum argues that it was not only desire for the beloved that caused the woman to leave her room at night but also jealousy; Hagerdorn, "Jealousy and Desire," 211-213. 
35 Hagerdorn, “Jealousy and Desire," 208.

36 Exum, "Ten Things," 31.

37 Exum, Song, 81.

38 Cheryl Exum, "Song of Songs," in Women's Bible Commentary, eds. Carol A. Newsom, Sharon H. Ringe and Jacqueline E. Lapsley; Twentieth-anniversary edition (Louisville, KY: Westminster John Knox, 2012), 248, 250; Meyers, "Gender Imagery," 210. 